\title{
Bioinformatics Resources in Facilitating Students' Conception on Molecule Genetics concepts
}

\author{
Tati Kristianti \\ Biology Education Program Study \\ Sekolah Tinggi Keguruan dan Ilmu \\ Pendidikan \\ Garut - Indonesia \\ kristianti007@yahoo.com \\ Sony Suhandono \\ Sekolah Ilmu dan Teknologi Hayati \\ Institut Teknologi Bandung \\ Bandung - Indonesia \\ Sony@sith.itb.ac.id
}

\author{
Ari Widodo \\ Fakultas Matematika dan Ilmu \\ Pengetahuan Alam \\ Universitas Pendidikan Indonesia \\ Bandung - Indonesia \\ widodo@upi.edu \\ Bruce Waldrip \\ Faculty of Education \\ Tasmania University \\ Hobart - Australia \\ Bruce.Waldrip@utas.edu.au
}

\begin{abstract}
Molecule genetics concepts are dificcult concepts for students almost in every country. Students must strugle to visualize those concepts. In this study, we presented bioinformatics resources in facilitating students' conception on molecule genetics concepts. Our research questions targeted students conception of deoxyriboculeic acid (DNA), transcription, genetic code, codon/anti-codon, intron, exon, gene. Data sources included pre/post-test and transcript of interviews. Our findings on pre-test showed that students have many variatian of molecule genetics concepts as prior knowledge. We found that most students held misconception of all over concepts and have partial conception on intron, exon and gene. Through bioinformatics learning process, the students prior conceptual frameworks was transformed to better understanding. Most students have a comprehensive knowledge of DNA, transcription, genetic code and codon/anti-codon. However most of students still held the partial knowledge of intron, exon and gene. Meanwhile in intron, exon and gene concepts, the students were unable to integrate their prior knowledge with informations of the bioinformatics resources. The transcripts revealed that bioinformatics resources were able to enhance students in representing of the DNA, transcription, genetic code and codon/anti-codon concepts.
\end{abstract}

Keywords-Molecule Genetics; Misconception; Bioinformatics; Learning Process.

\section{INTRODUCTION}

Molecules genetic concepts such as DNA, transcription (RNA), genetic code, codon/anti-codon, intron, exon and gene are still the most difficult concepts for may students all over the world. Meanwhile, genetics education has become increasing important with progressing of genetic engineering technologies. Bioinformatics is one of tools to explore and modify the results of genetic engineering. Bioinformatics is the application of computer technology to the management including storing, retrieving and analyzing of biological information such as DNA, RNA, amino acids and protein. Salter (1999) has recommended to use the bioinformatics resources as a tools learning. Recently many research have been done to use bioinformatics programe on-line or off-line as tools analysis and tools learning. Wefer \& Sheppard (2008) stated that bioinformatics cover 9 areas; 1) Human Genome Project/genomics, 2) forensics, 3) evolution, 4) classification, 5) nucleotide variations, 6) medicine, 7)computer use, 8) agriculture/food technology, and 9) science, technology and society/socioscientific issues (STS/SSI). All of areas will be a facilitating teacher to encourage students' in understanding of abstract concepts. Bioinformatics resources as learning tools to enhance students' understanding of DNA primers and their role in the Polymerase Chain Reaction process was used in Phillips et al., (2008) study. Free web-site bioinformatics tools to teach genetics from the phenotypic level to the molecular level was used in Grisham et al., (2010) study. Bioinformatics resources also was used to distance learning education by Olugbenga (2008).

The purposes of this study was to determined the influence of Bioinformatics resources in facilitating students' conception of molecule genetics concepts. Two research questions guided the design of this research :

1. How is students' variation understanding of molecule genetics concepts?

2. How is influence of the bioinformatics resources on students' conceptions?

Understanding the basic of cell and molecular inheritance have become a standard science in high schools education (NRC, 1996). However, to understand this concepts, the students must strugle to visualize this concepts. Chattopadhyay 
(2005) argued that the gap between classical and molecular genetics remains an obstacle to the development of a holistic concept of genetics because they are taught at different levels which often are not connected properly. The concept of genes, chromosomes, and alleles are rather abstract and can be better understood once students have a firm grasp of the structure and function of DNA and proteins (Roseman et al., 2006).

Learning bioinformatics is one of the learning strategies that engage students in retrieving, analyzing the data and making it as a medium for understanding the concept of molecular. Students must be involved in the learning process that can help build knowledge (Taylor, 2013).Bioinformatics has been used by Guadron et al. , (2010) as one way to allow students to achieve the advantages of a study in an unconventional way, so that students can gain a comprehensive understanding of genome science.Involving learners by conducting simulations with a computer in entering data sequences of DNA or proteins and subsequently analyzed by southern and westhern blotting, PCR , Single Nucleotide Polymorphism ( SNP ), expression microarray, ELISA and communicate online to peer results can provide the learning process attractive to learners (Bergland et al., 2012).Gelbart et al., (2009) used a simulation on the website bioinformatics programs to improve understanding of learners on the concept of genetics that allow learners to participate in the simulation authentic research with guided inquiry method. Bioinformatics based learning involves hands- on learners to use these data in the factual results of research from around the world and connect with the concepts of molecular biology. Therefore the involvement of learners build knowledge are essential in providing a deep understanding of learners to a concept. Another advantage of learning using bioinformatics tools can help learners to visualize abstract concepts such as DNA, RNA and protein synthesis can help learners to understand the basic concepts in the techniques of genetic engineering.

\section{RESEARCH METHOD}

This research method is descriptive study, and our study aims to investigate the influence of bioinformatics resources in facilitating students' conception on molecule genetics concepts. The population in this study is approximately 70 students who were studying biology education at Teaching and education college of Garut, West Java, Indonesia.

Bioinformatics resources-based learning was implemented into molecular biology course. During the course, we used constructivist learning strategy, as the material subjects course was divided from the simple one to the complex and the students' prior knowledge was important to follow the learning process. We encouraged students to explore the molecule genetics concept using bioinformatics resources, off-line and on-line programe.

Data were generated through students' responses on the pre and post-tes which conducted in each material subjects. The pre and post-test used in the form of essay-type questions. We tried to reveal all students' variation understanding on molecule genetics concepts. The validity of the students' responses was validated using interview. The students' responses were coded into four catagories of rubrics which developed by researchers (table 1) and modified from Kose method (2008).

TABLE I. DESCRIPTION OF EACH CATAGORIES

\begin{tabular}{|l|l|}
\hline \multicolumn{1}{|c|}{ Category } & \multicolumn{1}{c|}{ Description } \\
\hline No response & Student knows nothing about the term \\
\hline Incorrect & Student does not understand the term \\
\hline Incomplete & Student understands the term partially \\
\hline Complete & Student understands the term completely \\
\hline
\end{tabular}

\section{RESULTS AND DISCUSSION}

The students' variation understanding of molecule genetics concepts which identified through the responses were acquired by pre and post-test. The result of analysis of students' responses catagories is presented in the Figure 1. Based on the Figure 1 below, on pre-test showed that students held all variation conception for all concepts. We found some students still held no representation on almost all concepts. This finding similar to McDonald \& Gomes (2013) study. They found that most of students have no prior knowledge on molecule genetics concepts. Our finding also showed that some students have no standart competention in molecule genetics concepts. Since this is one of standart competention for high school students level (NRC, 1996). Most of students have incorrect knowledge on DNA and codon/anti-codon concepts. They determined the taging of 5' and 3' of double stranded DNA unproperly and they located codon and anticodon inversely or in the same location. Most of students have partial knowledge on transcription, intron, exon and gene. They just made definition of the term. McDonald \& Gomes (2013) study reported that transcription concept was one of difficulty concepts in molecular biology course. Wirght \&Newman (2014) study also showed the similiar results. Based on the students' responses of the post-test as follows figure 2, it showed an progressing of the percentage of students' responses into the better catagories. We did not find students who have no response. It means that they were able to adopt the information from bioinformatics resources to build their knowledge. Meanwhile we also found some students still held the incorrect knowledge of each material subjects in minor percentage than prior knowledge. It indicate that they were unable to used the bioinformatics resources in revising their knowledge. Form \& Lewitter (2011) proposed 10 implementation strategy of bioinformatics resources as tools of learning, namely : (1) make simple, (2) make familiar, (3) link with the existing curriculum, (4) develop activities that can build socialization between learners, (5) build skills through research-based inquiry, (6) allow independent learning for each learner, (7) direct learning model multiple, (8) powering the learners , (9) write the stages and learning outcomes, and (10) produce a conclusion the learning outcomes.

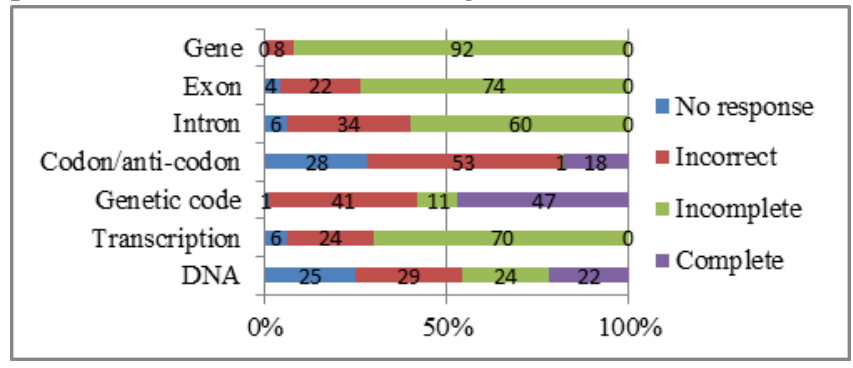

Fig. 1. Percent of pre-test students' response 


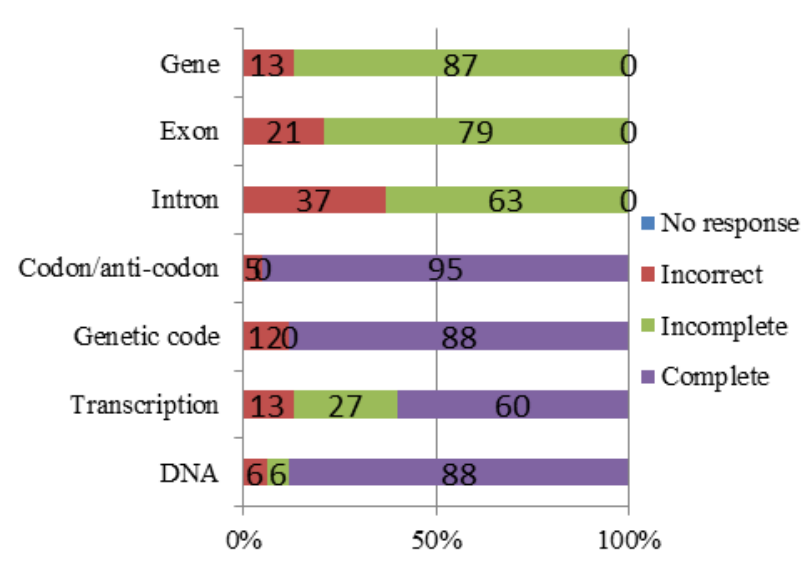

Fig. 2. Percent of post-test students' response

Therefore based on this results, we found most of students have complete understanding on DNA, transcription, genetic code and codon/anti-codon concepts. It seen that learn of molecule genetics concepts through bioinformatics resources was more effective in improving students conception on those concepts. Mean while we found that students' conception on intron, exon and gene were in static condition. The percentage of each catagories was not increase. Most of students still held the incorrect and incomplete understanding. This is the examples of students description on DNA on pre and post-test.

TABLE II. THE EXAMPLES OF STUDENTS REPRESENTATION ON DNA ON PRE AND POST-TEST

\begin{tabular}{|c|l|l|}
\hline \multirow{2}{*}{ Students } & \multicolumn{2}{|c|}{ Representation on DNA } \\
\cline { 2 - 3 } & \multicolumn{1}{|c|}{ (pre-test) } & \multicolumn{1}{|c|}{ (Post-test) } \\
\hline \multirow{2}{*}{1} & $\begin{array}{l}\text { Draw the double strands DNA } \\
\text { with no tagging 5' and 3' }\end{array}$ & $\begin{array}{l}\text { Draw the double strands } \\
\text { DNA with tagging5' dan } \\
\text { 3' properly. }\end{array}$ \\
\hline \multirow{2}{*}{3} & $\begin{array}{l}\text { Put the wrong pairs of purine } \\
\text { and Pyrimidine bases of DNA }\end{array}$ & $\begin{array}{l}\text { Put the paris of purine and } \\
\text { pyrimidine bases of DNA } \\
\text { properly }\end{array}$ \\
\hline & $\begin{array}{l}\text { Draw the double strands DNA } \\
\text { with Tagging 5' and 3' } \\
\text { pararel }\end{array}$ & $\begin{array}{l}\text { Draw the double strands } \\
\text { DNA with tagging 5' and } \\
\text { 3' in anti pararel. }\end{array}$ \\
\hline
\end{tabular}

As a learning outcomes and the course curriculum emphasize that students must understand to make the relationship of structure and function in biological systems. In this study we were looking for students to have the complete understanding who can incorporate both dimensions in their descriptions. For example on table 2, we found that some students did not put the tagging of $5^{\prime}$ and $3^{\prime}$ in end of each DNA strands. It indicated that they did not know what the function of the tagging 5' and 3' in double strands DNA. Their understanding would be impact of how they would be understand on transcription process. This finding similar with Bahar et al (1999) study that genetics difficulties have remained. McDonal \& Gomes (2013) study reported that introductory biology students struggle with the basic terminology necessary to understand the molecular and genetic level. Saka et al., (2006) and Dikmenli (2010) studies showed that teachers were unsatisfied to make connection on the molecular biology concepts. The similar finding was found by Chattopadhyay (2005) that students were unable to connect their understanding of gene with the chromosom. Marbach-Ad (2001) reported that twelfth grade students experience extensive difficulties in relating genetic concepts and they did not connect the concepts of gene and trait to more molecular concepts such as DNA, RNA and proteins.

Based on this study, we could seen that learn molecule genetics concepts through bioinformatics resources was more effective in improving students' conception on DNA, transcription, genetic code and codon/anti-codon concepts. Meanwhile, we found that students were unable to integrate their prior knowledge with bioinformatics resources into the better knowledge. This results was validated using interview. The transcripts revealed that bioinformatics resources were able to enhance the students in representing of the DNA, transcription, genetic code and codon/anti-codon concepts.Usually to visualize the abstract concept then do hands-on laboratory activities. Meanwhile this study presented the hands-on activities by in-silico using bioinformatics.Most bioinformatics software are available for free access for students. Maloney (2010) recommends a variety of bioinformatics -based learning model, namely:

1. Infusion bioinformatics content into existing subjects .

2. Linking biology and computer science with an interdisciplinary practice sharing.

3. Team -teaching bioinformatics involve instructors from various departments

Currently both database resources and bioinformatics programs have also been widely implemented as learning tools. Bioinformatics is not only owned by the researchers, but can be used by students to increase their knowledge. Rapid advances in bioinformatics as a new discipline has been a challenge to several universities to put it into the existing curriculum. Some educators are trying to start teaching in the curriculum to include bioinformatics.

\section{CONCLUSION}

Based on the results, it can be concluded that:

1. Students have variation understanding of genetic basic concept in all catagories ; no response, incorrect, incomplete and complete.

2. Learn genetics basic concepts through bioinformatics resources was more effective in improving students' conception on DNA, transcription, genetic code and codon/anti-codon concepts

\section{References}

[1] Bahar, M., Johnstone, A.H.\& Hansell, M.H.(1999). Revisiting learning difficulties in biology. Journal Biol. Educ. 33, pp. 84-86. DOI: 10.1080/00219266.1999.9655648

[2] Bergland M., Klyczek K., Lin C.C., Lundeberg M., R. Tosado-Acevedo, Toro A., White D. \& Wolter. B. (2012). Engaging Students in Molecular Biology via Case-Based Learning. Science, 337 
[3] Chattopadhyay A. (2005). Understanding of Genetic Information in Higher SecondaryStudents in Northeast India and the Implications forGenetics Education. Cell Biology Education. 4, pp 97-104

[4] Dikmenli M., Cardak O. \& Kiray S.A. (2011). Science Student Teachers' Ideas about the 'Gene' Concept. Procedia Social and Behavioral Sciences 15; pp 2609-2613

[5] Form D. \& Lewitter F. (2011). Ten Simple Rules for Teaching Bioinformatics at the High School Level. PLoS Computational Biology, $7: 10$

[6] Gelbart H.\& A. Yarden. (2009). The Impact of a Web-Based Research Simulationin Bioinformatics on Students' Understanding of Genetics. Res Sci Educ 39, pp 725-751. DOI 10.1007/s11165-008-9101-1

[7] Grisham W., Schottler N.A., Marill J.V., Beck L.\& Beatty J. (2010) Teaching Bioinformatics and Neuroinformatics by Using Free Webbased Tools. CBE-Life Sciences Education 9, pp. 98-107. DOI: 10.1187/cbe.09-11-0079

[8] Guadron L., , Alen M. Sajan, O. Plante, S. George \& Y. Gosser. (2010).Genome Science Education for Engineering Majors Fall 2010 Mid-Atlantic ASEE Conference, Villanova University

[9] Kose S. (2008). Diagnosing Student Misconceptions: Using Drawings as a Research Method.World Applied Sciences Journal 3 : 2, pp. 283-293

[10] Maloney M., Parker J., LeBlanc M., Woodard C.T., Glackin M.\& Hanrahan M. (2010). Bioinformatics and the Undergraduate Curriculum Essay. CBE-Life Sciences Education, 9, pp 172-174. DOI 10.1187/cbe.10-03-0038

[11] Marbach-Ad G., (2001. Attempting to break the code in student comprehension of genetic concepts. Journal of Biological Education35 :4, pp.183-189.

[12] McDonald K. \& Gomes J. (2013). Evaluating Student Preparedness and Conceptual Change in Introductory Biology Students Studying Gene Expression. Journal of Transformative Leadership and Policy Studies, 3 :

[13] National Research Council (1996). National science education standards Washington DC: National Academy Press

[14] Olugbenga. O.O. (2008). Development and Implementation of a Bioinformatics Online Distance Education Learning Tool for Africa. International Journal of Natural and Applied Sciences, $4: 3$, pp. 256262, 2008

[15] Phillips A.R., Robertson A.L., Batzli J., Harris M.\& Sarah M. (2008) Aligning Goals, Assessments, and Activities: An Approach to Teaching PCR and Gel Electrophoresis.CBE-Life Sciences Education, 7, pp. 96106

[16] Roseman, J., et al., (2006). The Annual Meeting of the National Association of Research in Science Teaching, San Francisco, CA.

[17] Salter H. (1998).Teaching bioinformatics. Biochcmical Education 26, pp3-I0

[18] Saka, A., Cerrah. L., Akdeniz, A.\& Ayas, A. (2006). A cross-age study of understanding of three genetic concepts: How do they image the gene, DNA, and chromo-some? Journal of Science Education and Technology. 2, pp 192-202. DOI: 10.1007/s10956-006-9006-6

[19] Taylor A. (2013). Commentary: Teaching Biochemistry and Molecular Biology in 3D: The New Next Generation Science Standards. Biochemistry and Molecular Biology $41: 5$, pp 348-350, Education. DOI 10.1002/bmb.20723

[20] Wefer, S.H.\& K. Sheppard. 2008. Bioinformatics in High School Biology Curricula: A Study of State Science Standards. Journal CBELife Science Education, 7, pp. 155-162

[21] Wirght L.K., Fisk J.N. \& Newman D.L. (2014). DNA $\rightarrow$ RNA: What Do Students Think the Arrow Means? CBE-Life Sciences Education, 13, pp 338-348, DOI: 10.1187 /cbe.CBE-13-09-0 
